\section{Long-term follow-up after resection of thyroid metastases from hepatocellular carcinoma in noncirrhotic liver}

\author{
Acompanhamento de longo prazo após a ressecção de metástases \\ na tiroide de carcinoma hepatocelular em fígado cirrótico
}

Ivonete Sandra de Souza e Silva', Adriano Miziara Gonzáles², Marcelo Moura Linhares ${ }^{2}$, Alcides Salzedas Neto ${ }^{3}$, Denis Szejnfeld ${ }^{4}$, Giuseppe D'Ippolito4, Gaspar de Jesus Lopes Filho ${ }^{2}$, Valeria Pereira Lanzoni ${ }^{5}$, Carla Adriana Matos ${ }^{1}$

\section{SUMMARY}

Thyroid metastasis from hepatocellular carcinoma $(\mathrm{HCC})$ is rare, and has poor prognosis. We report the case of a 62-year-old woman seen at our clinic because of the occurrence of a slightly painful abdominal mass. At that time, alpha-fetoprotein concentration was very high, reaching $49,831.7 \mathrm{ng} / \mathrm{mL}$. Abdominal ultrasound showed a heterogeneous mass in segment IV of the liver, which was diagnosed as $\mathrm{HCC}$ upon MRI.The patient underwent surgical resection and histological analysis of the specimen confirmed HCC. Metastases to the thyroid were detected 17 months after liver resection. Although the presence of metastases indicates advanced disease, thyroidectomy was performed, since no other distant metastases were detected. In fact, the patient is doing well 3 years after thyroidectomy and regular imaging exams showed no tumor recurrence. Current alpha-fetoprotein concentration is $8 \mathrm{ng} / \mathrm{mL}$. In conclusion, thyroid metastasis from $\mathrm{HCC}$ is uncommon and short-term survival is expected. However, surgical resection should be encouraged, especially in the case of solitary metastases. Arq Bras Endocrinol Metab. 2013;57(4):327-31

\section{SUMÁRIO}

As metástases de carcinoma hepatocelular $(\mathrm{CHC})$ em tiroide são raras e o prognóstico é ruim. Relatamos o caso de uma paciente de 62 anos de idade atendida em nossa clínica devido a uma massa abdominal levemente dolorida. Naquele momento, a concentração de alta-fetoproteína era muito alta, chegando a $49.831,7 \mathrm{ng} / \mathrm{mL}$. O ultrassom de abdômen mostrou uma massa heterogênea no segmento IV do fígado, que foi diagnosticada como $\mathrm{CHC}$ por meio de ressonância magnética. A paciente foi submetida a uma ressecção cirúrgica, e a análise histológica do espécime confirmou o $\mathrm{CHC}$. As metástases na tiroide foram detectadas 17 meses após a ressecção do fígado. Embora a presença de metástases indique doença avançada, a tiroidectomia foi feita porque não foram detectadas outras metástases distantes. De fato, três anos após a tiroidectomia, a paciente está bem e os exames de rotina mostraram não haver recorrência do tumor. $\mathrm{A}$ concentração atual de alfa-fetoproteína é de $8 \mathrm{ng} / \mathrm{mL}$. Concluiu-se que as metástases de $\mathrm{CHC}$ em tiroide não são comuns e espera-se uma sobrevida curta. Entretanto, deve-se encorajar a ressecção cirúrgica, especialmente no caso de metástases solitárias. Arq Bras Endocrinol Metab. 2013;57(4):327-31
1 Department of Gastroenterology, Hepatology Unit, Universidade Federal de São Paulo (Unifesp) São Paulo, SP, Brazil ${ }^{2}$ Department of Surgery, Liver Transplant Unit, Unifesp São Paulo, SP, Brazil

${ }^{3}$ Department of Pediatric Surgery, Unifesp, São Paulo, SP, Brazil ${ }^{4}$ Department of Diagnostic Radiology, Unifesp, São Paulo, SP, Brazil

${ }^{5}$ Department of Pathology, Unifesp, São Paulo, SP, Brazil

Correspondence to:

Ivonete Sandra de Souza e Silva Department of Gastroenterology, Universidade Federal de São Paulo Rua Botucatu, 740 04023-900 - São Paulo, SP, Brazil nett.isssilva@uol.com.br

Received on Jan/30/2013 Accepted on Feb/18/2013

\section{INTRODUCTION}

$\mathrm{H}$ epatocellular carcinoma (HCC) is the most common primary tumor of the liver and is responsible for more than 250,000 deaths worldwide every year (1). The natural history of HCC is devastating and mean survival is less than 1 year if untreated (2). Liver transplant and resection are considered to be curative treatments. Other therapeutic options exist, such as locoregional and systemic treatment. Locoregional treatment is a good choice and has been widely used with good response in terms of survival and maintenance of the patient on the liver transplant waiting list (3). Cur- 
rent systemic treatment is rapidly advancing but, so far, it has only shown slight increase in survival $(4,5)$. Short survival is observed for patients with distant metastases, even with the current treatments. The most common sites of metastases from HCC are the lungs, intra-abdominal lymph nodes, and bones (6,7). Many patients with metastases are in an advanced stage of liver disease; only few curative treatment options exist in these cases, and the prognosis is poor (8).

We report the rare case of a patient with HCC metastasizing to the thyroid after hepatectomy, and who presented a favorable clinical outcome after metastasis resection.

\section{CASE REPORT}

A 62-year-old woman sought the liver transplant service in September 2006 because of the occurrence of a slightly painful abdominal mass 6 months earlier. An abdominal ultrasound scan performed in August 2006 showed liver with preserved shape and size, slightly irregular contour, and finely heterogenous echotexture. A hyperechogenic and heterogenous mass with partially defined margins and lobulated contour, measuring $7.3 \times 5.8 \times 5.4 \mathrm{~cm}$, was detected in segment IV. The clinical history of the patient included thyroid goiter since 1970, and blood transfusion in 1986 due to an ectopic pregnancy. The patient reported no excessive alcohol consumption, use of medications, diabetes, high blood pressure, or dyslipidemia. General health status was good, and physical examination showed slightly enlarged thyroid due to goiter, and a hard abdominal mass with ill-defined margins located in the right upper quadrant. The body mass index of the patient was $22 \mathrm{~kg} / \mathrm{m}^{2}$.

Laboratory analysis of serum parameters showed the following results: aspartate aminotransferase, 114 $\mathrm{IU} / \mathrm{L}$; alanine aminotransferase, $220 \mathrm{IU} / \mathrm{L}$; alkaline phosphatase, $338 \mathrm{IU} / \mathrm{L}$; gamma-glutamyltransferase, $178 \mathrm{IU} / \mathrm{L}$; albumin, $4.2 \mathrm{~g} / \mathrm{dL}$; prothrombin time, 11.2 seconds; hemoglobin, $13.4 \mathrm{~g} / \mathrm{dL}$, and platelet count, $283,000 / \mu \mathrm{L}$. Thyroid function tests were normal. Serum alpha-fetoprotein was extremely high $(12,070.9 \mathrm{ng} / \mathrm{mL})$, reaching 49,831.7 ng/mL. Serology for hepatitis B and C virus was negative. No HCV RNA was detected by PCR. Serum iron tests were normal. Autoantibodies were negative.

Magnetic resonance imaging (MRI) of the abdomen performed 3 months later revealed the presence of three nodular formations in the liver, which presented the following characteristics: one nodular formation with well-defined margins and regular contour, measuring approximately $7.7 \times 3.8 \mathrm{~cm}$, located in segment IV. Contrast injection revealed early enhancement (arterial phase) associated with late capsule enhancement. Washout of tumor contrast material was seen on equilibrium-phase image. The findings indicated HCC. The two other nodular areas measuring $2.3 \times 1.9 \mathrm{~cm}$ and $0.9 \times 0.8 \mathrm{~cm}$, respectively, were located in segments II and VIII. Contrast injection revealed globule-like enhancement from the periphery to the center. The latter image probably corresponded to hemangiomas.

A workup for distant metastases including computed tomography (CT) of the lungs. ${ }^{99 \mathrm{~m} T c}$ bone scintigraphy was negative.

The tumor was treated by transcatheter arterial embolization (TACE), which reduced its size (Figure 1AB). However, the patient became intolerant after two sections of TACE, and the treatment was discontinued. After discussion of the case by radiologists, surgeons and physicians, the patient was placed on the liver transplant list. However, while waiting for a liver transplant, liver function tests remained normal and there was no evidence of portal hypertension or distant me-
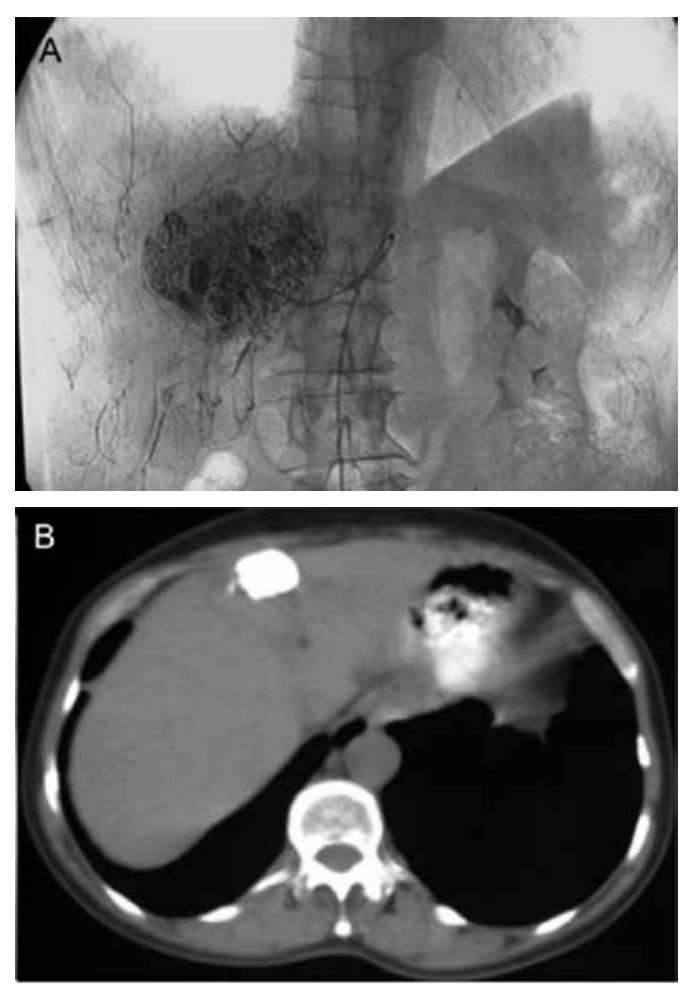

Figure 1. (A) Digital angiogram showing hypervascular liver nodule with diffuse lipiodol retention. (B) Axial computed tomography images showing a hepatic nodule in segment IV with homogenous and complete opacification and the presence of lipiodol. 
tastases. New discussion of the case led to the decision on hepatectomy. Anatomopathological examination of the partial hepatectomy specimen confirmed the diagnosis of HCC and showed a tumor measuring $3.5 \mathrm{~cm}$ in diameter (Figure 2A). The tumor grade was 2 according to the classification of Edmondson and Steiner. No microvascular invasion was observed and analysis of tumor-free liver samples showed steatohepatitis with an NAFLD activity score of 4 (Figure 2B-C) (9). TNM staging was $\mathrm{pTl}, \mathrm{pNx}, \mathrm{pMx}$. Other findings included a cavernous hemangioma measuring $2.5 \mathrm{~cm}$ in diameter. No liver cirrhosis, cholestasis, or portal vein thrombosis were found.
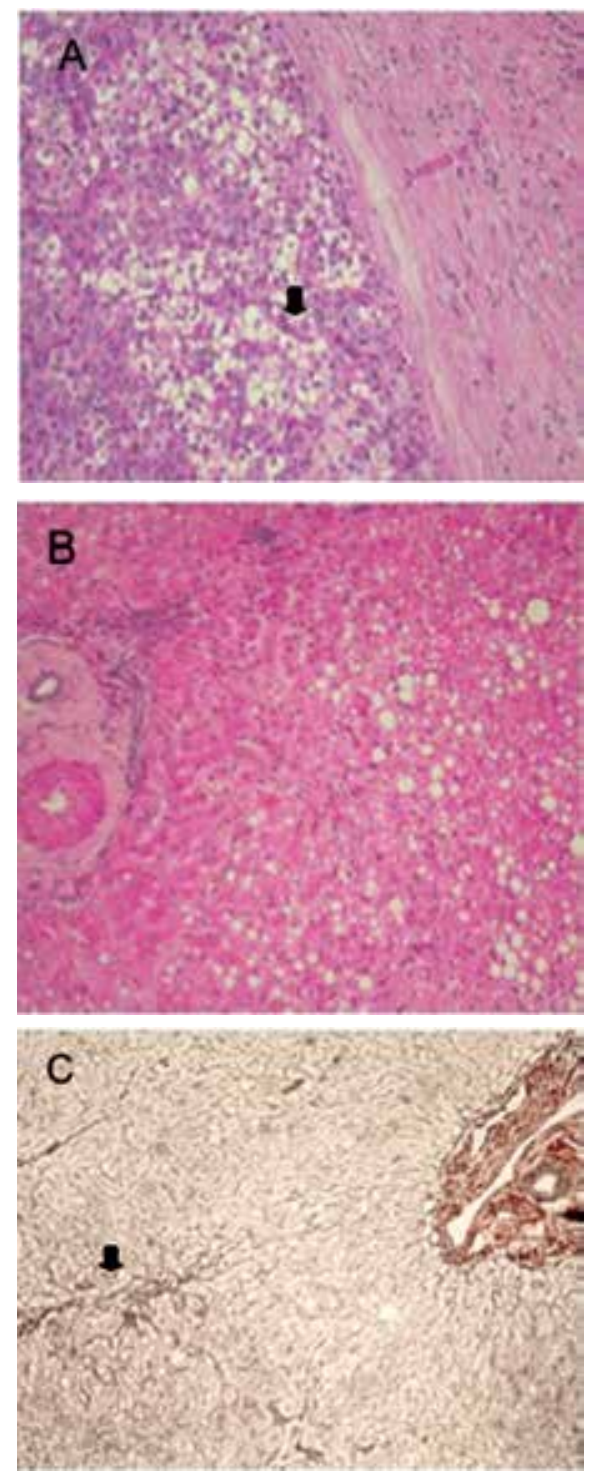

Figure 2. High-power microscopic view of liver slides showing: (A) Encapsulated hepatocellular carcinoma. Note the compact pattern with compressed sinusoids (H\&E). (B) Mild nonalcoholic steatohepatitis with steatosis in zone 3, hepatocyte ballooning degeneration (H\&E). (C) Perisinusoidal collagen deposition in zone 3 (reticulin).
After liver resection, the patient developed an intra-abdominal abscess that was treated using drainage and antibiotics. The patient required several months to recover. Serum alpha-fetoprotein levels continued to be high $(>30,000 \mathrm{ng} / \mathrm{mL})$, although no liver, lymph node, bone, or lung metastases could be detected by imaging exams. Seventeen months later, the patient complained of mild dysphagia and enlarged neck, which was identified by fine-needle aspiration as a secondary focus of HCC.

Since no further metastases were detected outside the liver, the patient recovered well from surgery, and there was no recurrence of HCC in the liver, solitary metastases in the thyroid were suspected and the patient underwent total thyroidectomy. Anatomopathological examination showed a thyroid gland weighing $362 \mathrm{~g}$ and measuring $16.0 \times 11.3 \times 5.5 \mathrm{~cm}$, and two nodules compatible with colloid goiter. There were two other metastatic nodules, the larger one measuring $7.5 \times 5.0 \mathrm{~cm}$. Tumor cells showed a distinctive histologic trabecular pattern (Figure 3A). Immunohistochemical staining showed that tumor cells were positive for monoclonal antibody HepPar-1 (Figure 3B), anticytokeratin (CAM-5.2), CD-10 (Figure $3 \mathrm{C}$ ), and polyclonal antiserum to carcinoembryonic antigen (pCEA). However, neoplastic cells were negative for thyroglobulin and thyroid transcription factor 1 . The immunological feature established the diagnosis of metastatic HCC to the thyroid (Figure 3).

Despite her advanced clinical disease, the patient is doing surprisingly well, and no recurrence of the tumor was detected by regularly imaging exams (MRI and bone scan) 3 years after thyroidectomy. In addition, alpha-fetoprotein concentration decreased to $8 \mathrm{ng} / \mathrm{mL}$ and continues to be normal.

\section{DISCUSSION}

Liver cancer is the third leading cause of cancer-related death, exceeded only by cancer of the lungs and stomach. HCC typically occurs in the setting of liver cirrhosis, especially when associated with hepatitis $\mathrm{C}$ or B virus infection and alcoholic cirrhosis. The development of metastases results in a poor prognosis. We report here the case of a patient with metastases to the thyroid that presented a long-term follow-up after resection. The clinical evolution of the patient has been satisfactory 4 years after tumor resection and 3 years after metastasis resection, without apparent recurrence of the tumor in the liver or other organs. 

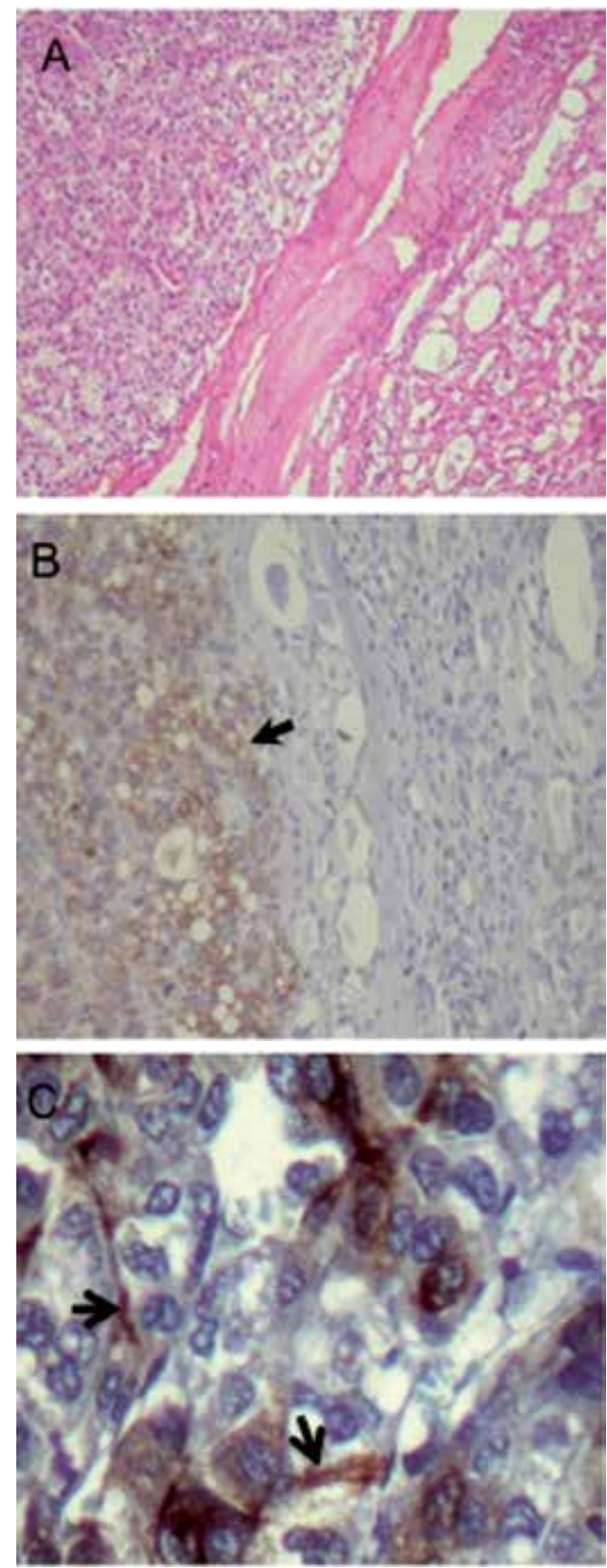

Figure 3. High-power microscopic view of thyroid slides showing: (A) Metastatic hepatocellular carcinoma (left) in thyroid (right) H\&E. (B) Cytoplasmic HepPar-1 staining on tumor cells (arrow). (C) CD10 immunostaining of bile canaliculi (arrows).

The most common sites of HCC metastases are the lungs (> 50\%), abdominal lymph nodes (41\%), and bones $(28 \%)(6)$. The adrenal glands are also frequently affected $(6,10)$. Metastases to the thyroid are rare and few cases have been reported in the literature. In fact, we found only four other cases of HCC with thyroid metastases prior to the present case (11-13). Therefore, the differential diagnosis with primary thyroid tumor is mandatory. In the present case, histological and immunohistochemical analysis of the surgical thyroid specimen left no doubts about the diagnosis of metastatic HCC.

The suspicion of metastases from HCC to the thyroid is very difficult due to the lack of symptoms, a fact that delays the diagnosis. Toshima and cols. (14) reported a similar case of a 74-year-old man who underwent hepatectomy for HCC. About 22 months later, des-gamma-carboxy prothrombin levels were elevated in the presence of normal alpha-fetoprotein. However, no recurrent HCC was detected using contrast-enhanced CT, bone scintigraphy, and upper gastrointestinal endoscopy. Physical examination revealed no palpable neck nodule and the patient had no symptoms. Only fluorine-18 fluorodeoxyglucose positron emission tomography/computed tomography (FDG-PET/CT) was able to detect a small nodule in the thyroid, which was confirmed to be metastatic HCC by fine needle biopsy. In the present case, alpha-fetoprotein levels remained high after hepatectomy, a finding that suggests the presence of a synchronous tumor, but this suspicion was not confirmed by imaging exams, although no PET/CT scan had been done. After 17 months, the patient complained of dysphagia when a new thyroid nodule was detected, and the biopsy confirmed a metastatic HCC to the thyroid. It is likely that the tumor was already present when the hepatectomy was performed.

The natural history of metastatic HCC is very short survival, and current treatments are somehow ineffective. Liang and cols. (12) reported a case of HCC metastases to the thyroid and lymph node involvement in a 54-year-old man who remained alive only about 8 months after thyroidectomy. At that time, liver HCC had relapsed. Advanced thyroid involvement and recurrence of HCC in the liver might have contributed to the short survival even after thyroid resection. In contrast, the present patient had no lymph node involvement, there was no recurrence of HCC in the liver, and the metastases to the thyroid appeared to be solitary. In addition, there was no evidence of liver cirrhosis and liver function was preserved as confirmed by serum liver function tests. In fact, the patient became symptom-free after thyroidectomy, serum alpha-fetoprotein levels decreased to the normal range, and subsequent imaging exams found no evidence of tumor recurrence in the liver or at any other distant sites. Therefore, the patient continues to be alive and tumor-free 3 years after thyroidectomy. 
We reported a rare case of HCC in noncirrhotic liver and metastases to the thyroid in a 62 -year-old woman, who presented an excellent unusual evolution. Complete resection of both the liver tumor and thyroid metastases solved the symptoms, and there were no signs of recurrence of the tumor. Therefore, surgical approach of solitary metastases from HCC may be considered, since it may prolong patient survival.

Disclosure: no potential conflict of interest relevant to this article was reported.

\section{REFERENCES}

1. Trinchet JC. Hepatocellular carcinoma: increasing incidence and optimized management. Gastroenterol Clin Biol. 2009;33(89):830-9.

2. Raoul JL. Natural history of hepatocellular carcinoma and current treatment options. Semin Nucl Med. 2008;38(2):S13-8.

3. Lee FT Jr. Treatment of hepatocellular carcinoma in cirrhosis: Iocoregional therapies for bridging to liver transplant. Liver Transpl. 2007;13(11 Suppl 2):S24-6.

4. Edeline J, Raoul JL, Vauleon E, Guillygomac'h A, Boudjema K, Boucher E. Systemic chemotherapy for hepatocellular carcinoma in non-cirrhotic liver: a retrospective study. World J Gastroenterol. 2009;15(6):713-6.
5. Llovet JM, Ricci S, Mazzaferro V, Hilgard P, Gane E, Blanc JF, et al. Sorafenib in advanced hepatocellular carcinoma. N Engl J Med. 2008;359(4):378-90.

6. Katyal S, Oliver JH 3rd, Peterson MS, Ferris JV, Carr BS, Baron RL. Extrahepatic metastases of hepatocellular carcinoma. Radiology. 2000;216(3):698-703.

7. Natsuizaka M, Omura T, Akaike T, Kuwata Y, Yamazaki K, Sato T, et al. Clinical features of hepatocellular carcinoma with extrahepatic metastases. J Gastroenterol Hepatol. 2005;20(11):1781-7.

8. OkusakaT, Okada S, Ishii H, Nose H, Nagahama H, Nakasuka $H$, et al. Prognosis of hepatocellular carcinoma patients with extrahepatic metastases. Hepatogastroenterology. 1997;44(13):251-7.

9. Kleiner DE, Brunt EM, Van Natta M, Behling C, Contos MJ, Cummings $\mathrm{OW}$, et al. Design and validation of a histological scoring system for nonalcoholic fatty liver disease. Hepatology. 2005;41(6):1313-21.

10. Yuki K, Hirohashi S, Sakamoto M, Kanai T, Shimosato Y. Growth and spread of hepatocellular carcinoma. A review of 240 consecutive autopsy cases. Cancer. 1990;66(10):2174-9.

11. Masuda T, Fukuya T, Ono M, Mitsuyama S, Toyoshima S. Thyroid metastasis from hepatocellular carcinoma as an initial presentation: a case report. Radiat Med. 2001;19(1):43-6.

12. Liang $\mathrm{HH}$, Wu CH, Tam KW, Chai CY, Lin SE, Chen SC. Thyroid metastasis in a patient with hepatocellular carcinoma: case report and review of literature. World J Surg Oncol. 2007;5:144.

13. Tsou PL, Chang TC. Ultrasonographic and cytologic findings of metastatic cancer in the thyroid gland. J Formos Med Assoc. 2001;100(2):106-12.

14. ToshimaT,Taketomi A, Shirabe K, Takeishi K, MotomuraT, ManoY, et al. Solitary asymptomatic thyroid metastasis from hepatocellular carcinoma detected by FDG-PET/CT. Case Rep Gastroenterol. 2010;4(2):279-85. 